\title{
A framework to evaluate the functionality of mobile applications for music composition
}

\author{
S VISAGIE $A N D$ CDE VILLIERS ${ }^{2}$
}

\begin{abstract}
:
The functionality of a diverse range of mobile applications for music composition is discussed in this paper. The focus is on generic functionality requirements, the needs of novice and expert users to compose music and some of the mobile applications for music composition available from the iTunes App Store. The paper further addresses the gap that exists in current literature about the functionalities required of mobile applications for music composition. In order to assist composers of music (from novices to experts) to identify and choose the most appropriate application for composing music on a mobile device, a framework is developed against which the functionality of ten mobile applications for music composition is evaluated.
\end{abstract}

Keywords: Transdisciplinarity, sound and music computing, mobile computing, mobile applications, music composition, functionality.

\section{Introduction}

Music, an expression of human emotions and a very powerful art form, has been around for centuries and can be regarded as a creative social process. The evolution of traditional instruments over time has created a multiple interaction mechanism for musicians to be creative and express themselves (Woldecke, Geiger, Reckter \& Schulz, 2010). Creating music on mobile devices is a popular and diverse topic in current research. A large number of mobile applications has been developed and these transform mobile devices into musical instruments, which enable individuals to compose and perform music (Savage, Ali \& Chavez, 2010; Zhou, Percival, Wang, Wang \& Zhao, 2010).

Music connects three groups: those who create music (composers), those who perform music (performers) and those who listen to and enjoy music (audience). Nowadays the audience can become creators of music even though they do not have an extensive background in composition. Mobile music is a relatively new term which refers to creating music on portable devices. This new movement has had an impact on current composers (Hamilton, Smith \& Wang, 2011) and the

1. Mrs Sonja Visagie is a $\mathrm{PhD}$ candidate in Informatics at the University of Pretoria. Email: sonjacloete@gmail.com

2. Prof. Carina de Villiers, is an academic member of staff in the Department of Informatics at the University of Pretoria. Email: carina.devilliers@up.ac.za

TD The Journal for Transdisciplinary Research in Southern Africa, 10(1) July 2014, pp. 87-111. 
authors support the notion that audience members are nowadays also users and active participants in the creation of music (Behrendt, n.d.).

This paper is aimed at two distinct academic disciplines: Music and Informatics. The structure of this paper is as follows. Firstly, the research questions will be defined and current literature will be reviewed. Secondly, background information on functionality will be provided and an overview of mobile applications for music composition will be presented. Based on these discussions an evaluation framework will be presented and applied to ten diverse mobile applications for music composition. Lastly the paper will conclude by answering the research questions.

\section{Research questions}

The following research question is raised:

- How can the functionality of mobile applications for music composition be evaluated?

The following secondary questions are raised:

- What is needed when composing music?

- How can music composers collaborate?

- What mobile applications are available for music composition?

Before attempting to answer these questions, the current literature is explored.

\section{Literature review}

\subsection{Background}

\subsubsection{Transdisciplinarity in Information Systems research}

Information Systems have become an integral component of business operations and is known for being pervasive in the way it creates business process efficiency. An example of how the music industry has changed because of technological advancements is how musicians use digital music stands for practising music and performances. Also, musicians use notation software and mobile applications to compose music. This was not possible in the past and has made the music industry much more accessible to individuals with no prior music training. This highlights the strong link between technology and the music industry and how strongly these two disciplines relate to each other.

The term 'multidisciplinary' describes the studying of a problem from different perspectives through collaboration efforts from a variety of disciplines. The field of Information Systems research has been recognised as being interdisciplinary because of various disciplines being integrated, and to broaden its scope it is said to become more transdisciplinary. By integrating different perspectives, interdisciplinarity focuses on the whole, while transdisciplinarity expands on this by highlighting the advantages that the contribution of new knowledge creates for society (Kroeze, 2012).

Transdisciplinarity includes a number of aspects. One known aspect is novelty; another is the creation of frameworks, especially evident and popular in Information Systems research and theory (Elliot, 2011). Creating a framework supports the integration of various perspectives. Transdisciplinarity focuses on problem-solving by assimilating concepts and approaches from different disciplines to solve problems (Kroeze, 2012). The aim of this paper is to contribute knowledge by providing a new framework for music composers to assist them in identifying suitable mobile applications for music composition based on the functionality of such applications. As there is 
a gap in research on mobile applications for music composition, this paper focuses on the disciplines of Music and Informatics and provides a novel practical solution to a complex problem - providing an evaluation framework to assist composers in identifying and utilising the right mobile applications.

\subsubsection{The field of Sound and Music Computing (SMC)}

Over the last 50 years music, sound and technology have become more connected and the format thereof has become increasingly digital. The link between computers and music can be traced back to the 1950s when teams consisting of composers, scientists and engineers started exploring the use of digital technology for the creation of music. This gave rise to the term 'computer music', which is related to music composition and the required tools and technologies. As methodologies from the fields of art, science and technology were combined it resulted in the multi-disciplinary area of research, which is today called Sound and Music Computing (SMC) or Musical Informatics, although SMC is the preferred term (Bernardini \& De Poli, 2007). The focus of SMC is on the integration of culture and Information and Communication Technologies (ICTs). The aim is to understand, model and create sound and music through the use of computational devices.

SMC falls within the human and natural sciences disciplines. The main academic categories are music (e.g. composition), science and technology (e.g. engineering) and psychology (e.g. experimental psychology). In the music category the focus of music composition is on designing sound and creating musical works (Bernardini \& De Poli, 2007).

Within SMC research there are different areas of application. One of these is digital music instruments where the focus is on devices that generate and process musical sound or the simulation of traditional musical instruments. Another such application is music production where the focus is on tools and technologies required for composing music, which can be any application used for the creation and modelling of music, to post-production and audio editing tools (Bernardini \& De Poli, 2007).

SMC has also been targeting areas other than those related to music, for example, music therapy and the mobile industry. However, it is perceived that researchers do not possess the required knowledge related to fundamental SMC topics such as the processes for creating music, multi-modal human computer interaction (the use of human senses to interact more naturally with automated systems) and cognition and perception and, therefore, there is a need for research contributions in music and the mobile industry (Bernardini \& De Poli, 2007).

Top SMC researchers from Europe have formed S2S2 (Sound to Sense, Sense to Sound) and presented a roadmap to define a strategic programme for this growing and diverse research field in order to address various challenges and to share research issues with the community that focuses on developments in industry and society (Bernardini \& De Poli, 2007).

Although the field of mobile music technology emerged around 2004 (Woldecke et al., 2010) when a number of researchers started exploring the idea of using mobile devices as musical instruments, commercialised mobile applications for music composition have only recently surfaced (Essl \& Rohs, 2009).

\subsubsection{Technological advances}

Information Systems, mobile applications in particular, have brought about many changes in business industries like the music industry. In the past composers recorded their compositions in pencil on music sheets. Nowadays they use music notation programs and recent developments in mobile applications for music composition. 
Mobile devices are increasingly used to simulate real musical instruments and have become popular tools for users to perform music interactively (Essl \& Rohs, 2009; Zhou et al., 2010). There is an expanding interest in creating music via mobile devices and since the mobility of technology has increased through the launch of mobile devices such as the iPhone, there has been an increase in mobile applications for music composition (Essl \& Rohs, 2009; Behrendt, n.d.).

One of the first devices in the field of mobile music creation, Roland's pocket-size sequencer and sound module PMS-5, was introduced in the middle 1990s. It operated on a touch screen interface and was created for professional musicians and hobbyists (Arrasvuori \& Holm, 2007) and not for casual users.

Since the introduction of mobile touch devices like the iPad, there has been development in professional applications in many industries. There is a need in the music industry for higher quality applications for music composition. The development of these, and especially professional applications, is very complex (Liu, Feng \& Li, 2012). Floch, Frá, Fricke, Geihs, Wagner, Lorenzo, Soladana, Mehlhase, Paspallis, Rahnama, Ruiz and Scholz (2012) agree that it is extremely complex to develop applications that are context-aware and self-adaptive and according to them there are no such applications in existence yet. The reason for this is a lack of software engineering support and few developers who have sufficient experience to develop such applications. Floch et al. (2012) propose an open-source framework called MUSIC, which could assist in the development of powerful, context-aware and self-adaptive mobile applications. The framework should focus on mobile applications that are self-adaptive and form part of the ubiquitous computing environment (Floch et al., 2012).

Technological advances, specifically the increase in the processing power and computing capabilities of mobile phones, have created an increase in the number of mobile music applications being developed (Savage et al., 2010; Behrendt, n.d.). This especially applies to the development of devices like the Apple iPhone and iPad which allow for ubiquitous computing possibilities and the creation of music in real time (Hamilton et al., 2011). Essl \& Rohs (2009) and Arrasvuori \& Holm (2007) state that mobile devices are regarded as ubiquitous as users carry them around like wallets or other small objects. They also mention that technology has been developing at a rapid pace and that mobile devices have computing power which increases with these technological advancements.

\subsubsection{Ubiquitous computing}

Ubiquitous computing in the field of music composition refers to the use of mobile applications without the users being consciously aware of the technology being used as it is seen as being part of the process and not something to continuously think about. It blends in with the user's environment and is not seen as an obstacle while being used. Chiang, Chiu, Dharma \& Tomimatsu (2012) also mention the technological advancements in ubiquitous computing where users do not notice the technology (hardware and software) that they utilise, as this is integrated into their environment.

The use of computers is not only on a personal level but has entered the field of pervasive computing (Hamilton et al., 2011). This means that users will increasingly use technology to support their everyday tasks although they will not be consciously aware of the technology they are using. The technology will remain in the background and be transparent while users complete a task. Users of mobile devices are not actively aware of the devices in their environment as these are already regarded as being integrated into their daily lives.

Arrasvuori \& Holm (2007) mention that many people own mobile phones and most downloads are inexpensive. According to Bernardini \& De Poli (2007) access to suitable technologies is an important factor if users wish to explore the digital era, specifically the enjoyment of music. 
Technological advancements, and specifically the digital divide, can be regarded as an entry barrier into the world of music composition. Not everyone has access to or can afford technologically advanced devices like smart phones and tablets.

\subsection{Functionality}

Functionality refers to the functions that should be supported by a music notation program or mobile application to enable a user to compose music. Although the focus of this paper is on mobile devices, it is worthwhile to mention that various music notation software packages are available for personal computers. A free program like MuseScore allows a user to set up a score, enter notes, play back the composition, add dynamics and lyrics - to mention but a few of its functionalities. Another popular proprietary program, Sibelius, allows the creation of professional scores and the ability to share compositions. Other top programs are Noteflight, Quickscore Elite and Notation Composer. Free trial downloads are available for most of these programs, but should a user require more functionality the complete program may be purchased.

Unfortunately academic literature on the functionality requirements for music composition using mobile devices is very limited. The following list was compiled by one of the authors of this study who has a music background and is a composer of music. It lists most of the functionality requirements for music composition:

- Mobile application type: Single / collaborative users

- Music sheets (staff and bars with bar numbers)

- Clef choice

- Key and time signature choice

- Metronome indicator

- Note and rest input on music sheet or from playing a mobile instrument

- Chord input

- Accidentals

- Note relationships

- Dynamics

- Articulation marks

- Ornaments

Important components for music education programs are creating works, listening effectively and performing works (Zhou et al., 2010). Music composers plan their use of musical instruments to create the sound they desire, whether it involves musicians playing in an orchestra or using electronic instruments in notation software or a mobile device application. Good orchestral composers are aware of the limitations and capabilities of musical instruments (Essl \& Rohs, 2009) and many challenges exist in using mobile devices for composing music (Woldecke et al., 2010). One such challenge is the small screen size of mobile phones.

Developers have to take a socio-technical approach when developing mobile applications for music composers. Music composition is regarded as an informal dialogue characterised by human interaction. This was evaluated by Bryan-Kinns (2004) in the framework of psychoanalytic theories of the relationship between mother and child in the early stages of development. The focus of the 
work was socially constructed and on music collaboration. Bryan-Kinns (2004) mentions that technology for individual and group composition highlights two concerns: firstly, basic tools for improvisation and creativity and secondly, robustness for creating and editing music.

Smart handheld devices are used by people who are on the move and users often work on more than one application at a time. They switch between multiple applications as their needs change (Floch $e t$ al., 2012). Mobile users can easily multi-task, for example, while working on an application, the user may take a phone call or send a text message while browsing the internet. It is important for developers to be aware of this as part of the context in which these mobile applications need to function.

Between 2001 and 2003 not many interactive mobile music applications existed (Arrasvuori \& Holm, 2007). According to Liu et al. (2012) no mobile applications exist for professional composers to interactively compose music, edit scores or track live performances because of the complexity of designing and programming these applications. The following features related to music composition are mentioned in their research:

- Music editing support (e.g. changing the score)

- Annotation in music sheets

- Music typesetting systems related to score layout guidelines

- Music symbol support

- Real-time audio feedback, like music score playback by choosing different instruments

- Playback of the performance and evaluation of the performance (acts like a music tutor)

- Turn sheet music pages

The dynamic nature of mobile computing environments is evident in changes to availability, quality, accessibility and usability. In order for users to use all of the features of a mobile application or to access enhanced functions, access to the internet is sometimes required. On the other hand, users may sometimes choose to use their mobile devices in offline mode and may decide to switch an application to offline mode to enhance battery life (Floch et al., 2012), for example. It would be useful to evaluate whether a user would be able to compose music if the mobile application is used offline. This forms part of the context-aware and self-adaptive computing environment mentioned by Floch et al. (2012).

People want to socially interact, collaborate and share with others who have similar interests, in this case, music composition. For this reason it is important that mobile applications for music composition have sharing capabilities, for example, emailing a composition in a suitable format, like MIDI, or uploading a musical composition to a social networking website like Facebook, Twitter, mySpace, YouTube, etc. A link could also be generated from the application that can, as with YouTube videos, be emailed to friends or family in order to share the composition without the complexity of emailing large files. Quick and easy sharing should be part of the functionality of these applications.

Bernardini \& De Poli (2007) highlight the importance of social interaction as part of innovative music products. Essl \& Rohs (2009) state that networking plays a critical role in composing music using mobile devices, but highlight certain security concerns. Hamilton et al. (2011) agree that mobile devices are regarded as tools that support musical creativity and that applications should allow the sharing of new musical creations on social websites like YouTube, Facebook and Twitter.

Because of rapid changes in technology and society, new research areas such as 'Social Networking through Music' (Bernardini \& De Poli, 2007) are introduced. Arrasvuori \& Holm (2007) state that 
users would want to store and share their musical creations with friends and that sharing should be made easy in future applications.

The importance of sharing is emphasised in the work of Smule, Inc. (Hamilton et al., 2011). Smule, Inc. has created various iOS platform-based social music applications. One example is a monophonic instrument for the iPhone called Ocarina. This application allows users to create melodies and share their musical creations. In the first six months after its release, this application was sold to over one million users and was a top seller in the iTunes App Store. Ocarina Songbook was later also released. This application allows users to upload and share compositions, add comments and contribute to improving musical works in a collaborative manner. Another application, Leaf Trombone, released in April 2009, is controlled by the user's breath and simulates a real trombone. The application even allows others to judge a work in the form of posted comments and scores from what is called the world stage. Magic Piano, a virtual piano, was created after the launch of the iPad in April 2010 and was introduced in a smaller free form in May 2011 for iPhone and iPod users. Within one week, more than one million users downloaded this application. A virtual violin, Magic Fiddle, was launched in November 2010 (Hamilton et al., 2011).

\subsection{Mobile applications for music composition}

The iTunes App Store was launched on 10 July 2008 (Hamilton et al., 2011). The App Store can be accessed through devices such as iPhones, iPads and iPod Touchs via an iOS application. By 18 January 2011 over 9,9 billion downloads had been made from the App Store. During July 2011 more than 15 billion applications were downloaded by 200 million iOS users and on 7 January 2013 Apple announced that more than 40 billion applications had been downloaded from the App Store (Wikipedia. App Store (iOS), 2013).

The ten mobile applications listed in table 3.1 below are some of the mobile applications for music composition available from the iTunes App Store (iTunes App Store, 2013). Prices range from $\$ 0.00$ to $\$ 8.99$. Most of the free applications allow limited functionality which would not cater for all the needs of expert users who might want to compose music on a more advanced level, especially users who have a music education background. A diverse range of mobile applications that include generic composing requirements as well as advanced requirements for novice and expert users were selected for this study. The level of complexity, related to the functionality of each application, is therefore diverse.

Table 3.1: Mobile applications for music composition (iTunes App Store, 2013)

\begin{tabular}{|c|c|c|c|c|}
\hline No. & Name & Description & Requirements & Price \\
\hline 1 & $\begin{array}{l}\text { Ocarina } 2 \\
\text { Version } 1.0 .8 \\
\text { by Smule }\end{array}$ & $\begin{array}{l}\text { Blow into your phone, play the notes, feel the } \\
\text { magic as Ocarina } 2 \text { responds to your breath, } \\
\text { touch and movement. Turn your phone into an } \\
\text { ancient flute-like instrument, and play the songs } \\
\text { you love. The sequel to the original, Ocarina } 2 \\
\text { now includes a completely new song mode. } \\
\text { Easily play and learn your favorite songs as } \\
\text { scores light up to guide your fingers. You control } \\
\text { the notes, speed and tempo, allowing your } \\
\text { expressivity to shine (Reference: } \\
\text { http://www.smule.com/ocarina/\#prettyPhoto). }\end{array}$ & $\begin{array}{l}\text { Requires iOS } 5.0 \text { or later. Compatible } \\
\text { with iPhone } 4 \text {, iPhone } 4 \mathrm{~S}, \text { iPhone } 5 \text {, } \\
\text { iPhone } 5 \mathrm{c}, \text { iPhone } 5 \mathrm{~s} \text {, iPad } 2 \mathrm{Wi}-\mathrm{Fi} \text {, } \\
\text { iPad } 2 \mathrm{Wi}-\mathrm{Fi}+3 \mathrm{G}, \mathrm{iPad} \mathrm{Wi}-\mathrm{Fi} \text { (3rd } \\
\text { generation), iPad Wi-Fi + Cellular } \\
\text { (3rd generation), iPad Wi-Fi (4th } \\
\text { generation), iPad Wi-Fi + Cellular } \\
\text { (4th generation), iPad mini Wi-Fi, } \\
\text { iPad mini Wi-Fi + Cellular, iPad Air, } \\
\text { iPad Air Wi-Fi + Cellular, iPad mini } \\
\text { with Retina display, iPad mini with } \\
\text { Retina display Wi-Fi + Cellular, iPod } \\
\text { touch (4th generation), and iPod } \\
\text { touch (5th generation). This app is } \\
\text { optimized for iPhone } 5 \text { (Reference: } \\
\text { https://itunes.apple.com/us/app/ocari }\end{array}$ & $\$ 0.00$ \\
\hline
\end{tabular}




\begin{tabular}{|c|c|c|c|c|}
\hline & & & na-2/id525944697). & \\
\hline No. & Name & Description & Requirements & Price \\
\hline 2 & $\begin{array}{l}\text { Piano DX } \\
\text { Version } 1.1 \text { by } \\
\text { Daniel Perez }\end{array}$ & $\begin{array}{l}\text { Piano DX is the best piano app available for your } \\
\text { iPhone, iPod Touch, and iPad. It has more } \\
\text { features than any other piano app, many of which } \\
\text { are available nowhere else. It is a full } 88 \text { key } \\
\text { piano with every option you could ever want } \\
\text { including multitouch, rich sound, adjustable } \\
\text { metronome, sustain pedal, double row keyboard, } \\
\text { retina display graphics and much much more. } \\
\text { Best of all, the piano and all of its features are } \\
\text { completely FREE! (Reference: } \\
\text { https://itunes.apple.com/us/app/piano-dx- } \\
\text { free/id403588421?mt=8). }\end{array}$ & $\begin{array}{l}\text { Requires iOS } 3.0 \text { or later. Compatible } \\
\text { with iPhone, iPad, and iPod touch } \\
\text { (Reference: } \\
\text { https://itunes.apple.com/us/app/pian } \\
\text { o-dx-free/id403588421?mt=8). }\end{array}$ & $\$ 0.00$ \\
\hline 3 & $\begin{array}{l}\text { iWriteMusic- } \\
\text { Free Version } \\
2.3 .4 \text { by } \\
\text { iWriteMusicP } \\
\text { roject }\end{array}$ & $\begin{array}{l}\text { The one and only full-scale music notation editor } \\
\text { for iPhone and iPod Touch. With this highly } \\
\text { practical and intuitive user interface, iWriteMusic } \\
\text { will help you prepare sheet music for rehearsals, } \\
\text { music lessons, home assignments and so on } \\
\text { anywhere, anytime! (Reference: } \\
\text { https://itunes.apple.com/us/app/iwritemusic- } \\
\text { free/id393614358?mt=8). }\end{array}$ & $\begin{array}{l}\text { Requires iOS } 7.0 \text { or later. Compatible } \\
\text { with iPhone, iPad, and iPod touch. } \\
\text { This app is optimized for iPhone } 5 \\
\text { (Reference: } \\
\text { https://itunes.apple.com/us/app/iwrit } \\
\text { emusic-free/id393614358?mt=8). }\end{array}$ & $\$ 0.00$ \\
\hline 4 & $\begin{array}{l}\text { Music Studio } \\
\text { Lite Version } \\
2.4 .1 \text { by } \\
\text { Alexander } \\
\text { Gross }\end{array}$ & $\begin{array}{l}\text { Music Studio offers a complete music production } \\
\text { environment for the iPad/iPhone/iPod Touch with } \\
\text { features and a sound quality previously only } \\
\text { known to desktop applications and expensive } \\
\text { audio hardware (Reference: } \\
\text { https://itunes.apple.com/en/app/music-studio- } \\
\text { lite/id378356692?mt=8). }\end{array}$ & $\begin{array}{l}\text { Requires iOS } 5.1 \text { or later. Compatible } \\
\text { with iPhone, iPad, and iPod touch. } \\
\text { This app is optimized for iPhone } 5 \\
\text { (Reference: } \\
\text { https://itunes.apple.com/en/app/musi } \\
\text { c-studio-lite/id378356692?mt=8). }\end{array}$ & $\$ 0.00$ \\
\hline No. & Name & Description & Requirements & Price \\
\hline 5 & $\begin{array}{l}\text { Maestro - the } \\
\text { Music } \\
\text { Composition } \\
\text { App Version } \\
2.6 \text { by Darren } \\
\text { Gates }\end{array}$ & $\begin{array}{l}\text { Now you can create real music compositions on } \\
\text { your iPhone or iPod Touch using Maestro! You } \\
\text { can create simple, treble-clef musical notation by } \\
\text { simply dragging notes and rests to the stanza, } \\
\text { play it for a friend, and save it for later editing } \\
\text { (Reference: } \\
\text { https://itunes.apple.com/en/app/maestro-music- } \\
\text { composition/id358173811?mt=8). }\end{array}$ & $\begin{array}{l}\text { Compatible with iPhone, iPod touch, } \\
\text { and iPad. Requires iOS } 3.1 .2 \text { or later } \\
\text { (Reference: } \\
\text { https://itunes.apple.com/en/app/maes } \\
\text { tro-music- } \\
\text { composition/id358173811?mt=8). }\end{array}$ & $\$ 0.99$ \\
\hline 6 & $\begin{array}{l}\text { Pianist } \\
\text { Version } 1.9 \text { by } \\
\text { MooCowMusi } \\
\text { c Ltd. }\end{array}$ & $\begin{array}{l}\text { The first widely available mobile multi-touch } \\
\text { piano, Pianist has been featured in a number of } \\
\text { Apple advertising campaigns, been consistently } \\
\text { in the iTunes Top } 100 \text { Music Apps list, and was } \\
\text { one of the 'Awesome iOS4 Apps' in an Apple } \\
\text { iTunes promotion. Sound On Sound magazine } \\
\text { listed Pianist in its pick of the Top } 20 \text { iPhone } \\
\text { Apps, and T3 Magazine in its Top } 100 \text { iPhone } \\
\text { Apps. Pianist has also been recommended by } \\
\text { media sources such as the Mail On Sunday and } \\
\text { Fox News (Reference: } \\
\text { https://itunes.apple.com/en/app/pianist/id284622 } \\
652 \text { ?mt=8). }\end{array}$ & $\begin{array}{l}\text { Requires iOS } 5.0 \text { or later. Compatible } \\
\text { with iPhone, iPad, and iPod touch. } \\
\text { This app is optimized for iPhone } 5 \\
\text { (Reference: } \\
\text { https://itunes.apple.com/en/app/piani } \\
\text { st/id284622652?mt=8). }\end{array}$ & $\$ 3.99$ \\
\hline 7 & $\begin{array}{l}\text { Music } \\
\text { Composer } \\
\text { Version } 2.4 \text { by } \\
\text { Kejian Jin }\end{array}$ & $\begin{array}{l}\text { This application is a virtual piano for the iPhone } \\
\text { or iPod device. It also allows score editing and } \\
\text { automatically generate sound file and music } \\
\text { notation sheet (Reference: } \\
\text { http://itunes.apple.com/za/app/id302221931). }\end{array}$ & $\begin{array}{l}\text { Requires iOS } 4.3 \text { or later. Compatible } \\
\text { with iPhone, iPad, and iPod touch. } \\
\text { This app is optimized for iPhone } 5 \\
\text { (Reference: } \\
\text { http://itunes.apple.com/za/app/id302 } \\
\text { 221931). }\end{array}$ & $\$ 3.99$ \\
\hline
\end{tabular}




\begin{tabular}{|c|c|c|c|c|}
\hline No. & Name & Description & Requirements & Price \\
\hline 8 & $\begin{array}{l}\text { Symphony } \\
\text { Version } 2.6 .4 \\
\text { by Xenon } \\
\text { Labs, LLC }\end{array}$ & $\begin{array}{l}\text { Symphony is a multi-track music notation editor } \\
\text { that allows you to compose and playback songs } \\
\text { from wherever you are. You can easily import in } \\
\text { any MIDI file, open an existing composition, or } \\
\text { start from scratch. Once you are done working on } \\
\text { a piece, you can export it and continue working } \\
\text { on it in whichever program you like (Reference: } \\
\text { http://itunes.apple.com/za/app/id329669701). }\end{array}$ & $\begin{array}{l}\text { Requires iOS } 3.1 .3 \text { or later. } \\
\text { Compatible with iPhone, iPad, and } \\
\text { iPod touch (Reference: } \\
\text { http://itunes.apple.com/za/app/id329 } \\
\text { 669701). }\end{array}$ & $\$ 4.99$ \\
\hline 9 & $\begin{array}{l}\text { iComposer } \\
\text { Version } 2.0 .3 \\
\text { by JL }\end{array}$ & $\begin{array}{l}\text { iComposer } 2 \text { is a comprehensive smart Music } \\
\text { Notation Tool for sheet music reading and } \\
\text { editing. With iComposer you can read or create or } \\
\text { share sheet music anytime anywhere (Reference: } \\
\text { http://itunes.apple.com/za/app/id317175102). }\end{array}$ & $\begin{array}{l}\text { Requires iOS } 3.0 \text { or later. Compatible } \\
\text { with iPhone, iPad, and iPod touch } \\
\text { (Reference: } \\
\text { http://itunes.apple.com/za/app/id317 } \\
\text { 175102). }\end{array}$ & $\$ 8.99$ \\
\hline 10 & $\begin{array}{l}\text { iWriteMusic } \\
\text { Version } 2.3 .4 \\
\text { by } \\
\text { iWriteMusicP } \\
\text { roject }\end{array}$ & $\begin{array}{l}\text { The one and only full-scale music notation editor } \\
\text { for iPhone and iPod Touch. With this highly } \\
\text { practical and intuitive user interface, iWriteMusic } \\
\text { will help you prepare sheet music for rehearsals, } \\
\text { music lessons, home assignments and so on } \\
\text { anywhere, anytime! (Reference: } \\
\text { http://itunes.apple.com/za/app/id393624808). }\end{array}$ & $\begin{array}{l}\text { Requires iOS } 7.0 \text { or later. Compatible } \\
\text { with iPhone, iPad, and iPod touch. } \\
\text { This app is optimized for iPhone } 5 \\
\text { (Reference: } \\
\text { http://itunes.apple.com/za/app/id393 } \\
\text { 624808). }\end{array}$ & $\$ 8.99$ \\
\hline
\end{tabular}

\subsection{Summary}

In the literature review a short summary of transdisciplinarity in Information Systems research related to this paper was provided. A summary was also given of the field of SMC, the technological advances experienced in the music industry and the notion of ubiquitous computing. In order to have been able to compile the evaluation framework that will be discussed in the next section, the functionality of mobile applications for music composition was described. Unfortunately, few articles have been published on the functionality of mobile applications for music composition and, hopefully, this gap is addressed by the research done in the next section. Later in this paper the evaluation framework will be applied to the ten diverse music composition applications mentioned in table 3.1 above.

\section{Evaluation framework}

The purpose of the evaluation framework is to assist music composers, from novices to experts, in identifying and choosing the most suitable and usable application for composing music on a mobile device. The framework targets music composers and aims at assisting them in finding the best match between their composing requirements and the mobile application functionality.

The functionality category was chosen for the evaluation framework because it was most evident in the literature. A questionnaire was developed to assess the importance of various functionality criteria related to mobile applications for music composition. The initial list of functionality criteria for the questionnaire (see section 3.2 above) was created by one of the authors who is involved in music composition, plays two instruments (the violin and the piano) and has a theoretical music background. The author has sufficient knowledge of the requirements needed for music composition through the use of mobile applications.

The questionnaire was completed by seven music lecturers and five music students involved with music at tertiary level. The respondents were asked to rate the importance of each functionality criterion relating to composing music using a mobile application, by choosing one of three categories: 'Not important'; 'Important'; 'Very important'.

Some interesting results were noted from the questionnaire. All the lecturers and students considered editing the composition as being very important and the majority of lecturers and all the students 
considered saving the composition as very important. It was also noted that the majority of students have used a mobile application to compose music in the past. This trend was more evident with the student than the lecturer respondents and was also related to the age group between 18 and 29 .

One lecturer added the following additional comment: "I am not a composer, but as a player I consider the above as very important to read the music". One student added the following additional comment: "At the moment there aren't that many music composition apps available for MAC/Android products.”

Based on the literature, one of the author's knowledge of music and the results from the questionnaire, the authors developed a framework for the evaluation of the functionality of a diverse range of mobile applications for music composition.

The evaluation criteria are grouped into three sub-categories which link the functionality requirements to the type of users and emphasise different levels of requirements. The three subcategories are 'Generic', 'Novice' and 'Expert'. The generic sub-category refers to the general functionality requirements of the applications, irrespective of the type of user. In this paper a novice user refers to any individual with a basic music education background who has completed a music theory programme not higher than a grade two level. In this paper an expert user refers to an individual who has completed a music theory programme at least up to a grade six level and refers to individuals such as music lecturers and music students at tertiary level.

In South Africa music students of any age are able to register for and complete their music theory through the University of South Africa (UNISA). UNISA offers eight music theory grades and after completion thereof an individual may register for and complete a music theory teacher's licentiate.

The framework for the evaluation of the functionality of mobile applications is presented in table 4.1 below:

Table 4.1: A framework to evaluate mobile application functionality for music composition

\begin{tabular}{|l|l|}
\hline FUNCTIONALITY EVALUATION CRITERIA & SOURCE \\
\hline GENERIC & Author; Arrasvuori \& Holm (2007) \\
\hline Mobile application type: Single / collaborative users & Author; Questionnaire results \\
\hline Music sheets (staff and bars with bar numbers) & Liu et al.(2012); Questionnaire results \\
\hline Turn music sheet pages & $\begin{array}{l}\text { Author; Liu et al.(2012); Questionnaire } \\
\text { results }\end{array}$ \\
\hline $\begin{array}{l}\text { Instrument choice (range of instruments) } \\
\text { Real-time audio feedback }\end{array}$ & $\begin{array}{l}\text { Author; Liu } \text { et al.(2012); Questionnaire } \\
\text { results }\end{array}$ \\
\hline $\begin{array}{l}\text { Music score playback at any stage } \\
\text { Counterpoint (e.g. two or three melodic lines played at the same time) }\end{array}$ & $\begin{array}{l}\text { Author; Liu } \text { et al.(2012); Questionnaire } \\
\text { results }\end{array}$ \\
\hline $\begin{array}{l}\text { Composition editing (clef, key signature, time signature, notes and rests, } \\
\text { instrument, etc.) }\end{array}$ & $\begin{array}{l}\text { Author; Liu } \text { et al.(2012); Questionnaire } \\
\text { results }\end{array}$ \\
\hline $\begin{array}{l}\text { Save composition to server or device or in other suitable and usable } \\
\text { format (MIDI, etc.) }\end{array}$ & \begin{tabular}{l} 
Author; Questionnaire results \\
\hline
\end{tabular}
\end{tabular}




\begin{tabular}{|c|c|}
\hline $\begin{array}{l}\text { Sharing capabilities by generating a link or uploading composition to a } \\
\text { social networking website (YouTube, Facebook, Twitter, mySpace, etc.) }\end{array}$ & $\begin{array}{l}\text { Author; Arrasvuori \& Holm (2007); } \\
\text { Bernardini \& De Poli (2007); Essl \& Rohs } \\
\text { (2009); Hamilton et al.(2011); } \\
\text { Questionnaire results }\end{array}$ \\
\hline Context-aware and self-adaptive: Online / Offline & $\begin{array}{l}\text { Author; Floch et al.(2012); Questionnaire } \\
\text { results }\end{array}$ \\
\hline Track live performance & Liu et al.(2012); Questionnaire results \\
\hline Evaluation of performance (acts like a music tutor) & Liu et al.(2012); Questionnaire results \\
\hline \multicolumn{2}{|l|}{ NOVICE } \\
\hline $\begin{array}{l}\text { Clef choice (the symbol at the start of the staff that defines the pitch of } \\
\text { the notes - Treble; Bass; Alto / Tenor) }\end{array}$ & $\begin{array}{l}\text { Author; Liu et al.(2012); Questionnaire } \\
\text { results }\end{array}$ \\
\hline $\begin{array}{l}\text { Key signature choice (flat or sharp: shown at the start of the staff that } \\
\text { indicates the music key) }\end{array}$ & Author; Questionnaire results \\
\hline $\begin{array}{l}\text { Time signature choice (the tempo at the start of the staff, after the key } \\
\text { signature, that indicates the tempo of the music) }\end{array}$ & Author; Questionnaire results \\
\hline Metronome indicator $(\mathrm{d}=120)$ & Author; Questionnaire results \\
\hline Note and rest input on music sheet or from playing a mobile instrument & Author; Questionnaire results \\
\hline Chord input (e.g. three or four notes played simultaneously in harmony) & Author; Questionnaire results \\
\hline Accidentals (flat, sharp, natural, etc.) & Author; Questionnaire results \\
\hline Dynamics (e.g. ff, f, mf, pp, p, mp, etc.) & Author; Questionnaire results \\
\hline Octave signs $(8$, etc. $)$ & Author; Questionnaire results \\
\hline \multicolumn{2}{|l|}{ EXPERT } \\
\hline Note relationships (tie, slur, etc.) & Author; Questionnaire results \\
\hline $\begin{array}{l}\text { Articulation marks (staccato, accent, fermata, strings: up and down } \\
\text { bow) }\end{array}$ & Author; Questionnaire results \\
\hline Ornaments (modifies pitch pattern: trill, mordent, appoggiatura, etc.) & Author; Questionnaire results \\
\hline Break input (' or //) & Author; Questionnaire results \\
\hline Repetition and coda signs (repeat signs, etc.) & Author; Questionnaire results \\
\hline Transposition (move notes up or down in pitch by a constant interval) & Author; Questionnaire results \\
\hline Modulation (shift to another key at any stage) & Author; Questionnaire results \\
\hline
\end{tabular}

\subsection{Research findings}

\subsection{Research method}

An interpretive approach was used and the authors remained subjective to the study. The research perspective adopted was qualitative because of the interpretation of the functionality of mobile applications for music composition. There was a need for a clear understanding of the functionality of these mobile applications by using systematic observation.

According to Chen \& Hirschheim (2004) a reason for the predominant adoption of interpretivism and qualitative methods is that it offers support to better investigate the research questions and to 
enhance an in-depth understanding of the phenomenon. Weber (2004) mentions validity and reliability concerns regarding the interpretivist approach. The context of the study will impact on the research contribution as the authors believe that objects change when placed in different contexts. Thus, the authors do not believe that generalisations can be made about the functionality of mobile applications for music composition, as these were studied in a specific context. Floch et al. (2012) conducted much research in the field of context-aware computing and emphasise the importance of developing context-aware and self-adaptive mobile applications.

In this study the authors used systematic observation. Systematic observation involves one or more observers who observe subjects' behaviour or events (Vonk, Tripodi \& Epstein, 2007). In this case the functionality of ten mobile applications was observed. According to Research Design (2013) it is important that the observer is familiar with the context and categories of the observation. As was mentioned before, one of the authors of this study has a music background and created the initial list of functionality criteria which was confirmed with the results obtained from the questionnaire. This list was used as the field notes to do the observations.

In this study, from 20 November to 10 December 2012, the authors downloaded ten mobile applications (table 3.1) for music composition from the iTunes App Store and observed the functionality of these mobile applications while practising music composition on each application. Each mobile application was evaluated against the functionality criteria listed in table 4.1 in order to evaluate the overall functionality of the ten mobile applications for music composition.

An important aspect of systematic observation is the systematic recording of observed behaviour (Research Design, 2013). The recording can be done by using a checklist, a form or ratings. In this study, the focus was on observing the functionality of the mobile applications by making notes, similar to a checklist, under pre-determined functionality criteria as stated in table 4.1. Systematic observation is also useful for research evaluation (Vonk et al., 2007) and in this study ten mobile applications for music composition were evaluated highlighting the relevance of the use of this method.

\subsection{Research results}

The authors downloaded ten mobile applications for music composition from the iTunes App Store and practised music composition on each application. The device used for this purpose was an Apple iPhone. A considerable amount of time was spent evaluating the functionality of each application. The first five applications evaluated are listed in table 5.1 and the last five applications in table 5.2 below. These tables list the results of the evaluation of the ten mobile applications for music composition indicated in table 3.1 based on the functionality evaluation criteria set out in table 4.1. 


\begin{tabular}{|c|c|c|c|c|c|}
\hline FUNCTIONALITY EVALUATION CRITERIA & $\begin{array}{l}\text { Ocarina } 2 \text { Version } \\
1.0 .8 \text { by Smule }\end{array}$ & $\begin{array}{l}\text { Piano DX Version } \\
1.1 \text { by Daniel Perez }\end{array}$ & $\begin{array}{l}\text { iWriteMusic-Free } \\
\text { Version } 2.3 .4 \text { by } \\
\text { iWriteMusic } \\
\text { Project }\end{array}$ & $\begin{array}{l}\text { Music Studio Lite } \\
\text { Version 2.4.1 by } \\
\text { Alexander Gross }\end{array}$ & $\begin{array}{l}\text { Maestro - the } \\
\text { Music Composition } \\
\text { App Version } 2.6 \text { by } \\
\text { Darren Gates }\end{array}$ \\
\hline \multicolumn{6}{|l|}{ GENERIC } \\
\hline Mobile application type: Single / collaborative users & Single & Single & Single & Single & Single \\
\hline Music sheets (staff and bars with bar numbers) & No & $\begin{array}{l}\text { No. Only when } \\
\text { learning (observing or } \\
\text { playing). }\end{array}$ & $\begin{array}{l}\text { Yes. Staff, bars and } \\
\text { bar numbers. }\end{array}$ & No & $\begin{array}{l}\text { Yes. Staff and bars. } \\
\text { No bar numbers. }\end{array}$ \\
\hline Turn music sheet pages & No & No & Yes & No & Yes \\
\hline Instrument choice (range of instruments) & $\begin{array}{l}\text { Yes. Not a range. Can } \\
\text { change settings. See } \\
\text { 'Other'. }\end{array}$ & No. Only piano. & Yes. There is a range. & Yes. There is a range. & Yes. There is a range. \\
\hline Real-time audio feedback & Yes, as a user plays. & Yes, as a user plays. & $\begin{array}{l}\text { Yes, as a user taps to } \\
\text { insert notes. }\end{array}$ & Yes, as a user plays. & No \\
\hline Music score playback at any stage & $\begin{array}{l}\text { Yes, when finished. } \\
\text { Not at any stage. }\end{array}$ & No & Yes & $\begin{array}{l}\text { Yes. Has a record and } \\
\text { playback function. }\end{array}$ & Yes \\
\hline $\begin{array}{l}\text { Multiple melodic lines captured and simultaneous playback: } \\
\text { Counterpoint (e.g. two or three melodic lines played at the same } \\
\text { time) }\end{array}$ & No & $\begin{array}{l}\text { Yes, on dual keyboard, } \\
\text { but no playback. }\end{array}$ & Yes & Yes & No \\
\hline $\begin{array}{l}\text { Composition editing (clef, key signature, time signature, notes } \\
\text { and rests, instrument, etc.) }\end{array}$ & $\begin{array}{l}\text { Yes. Key signature. } \\
\text { Instrument settings } \\
\text { can be changed. See } \\
\text { 'Other'. }\end{array}$ & $\begin{array}{l}\text { No. Only real-time } \\
\text { playing. Can adjust } \\
\text { volume. }\end{array}$ & Yes. All functions. & $\begin{array}{l}\text { Yes. Can change and } \\
\text { delete notes. Has an } \\
\text { undo function. Can } \\
\text { move notes a semitone } \\
\text { or octave up and } \\
\text { down. Has many } \\
\text { effects (limiter, reverb, } \\
\text { delay, equaliser, } \\
\text { amplifier, filter, pitch). }\end{array}$ & $\begin{array}{l}\text { Yes. Cannot change } \\
\text { Clef at any stage. } \\
\text { Select at start. Can } \\
\text { change and delete } \\
\text { notes by dragging. }\end{array}$ \\
\hline
\end{tabular}




\begin{tabular}{|c|c|c|c|c|c|}
\hline FUNCTIONALITY EVALUATION CRITERIA & $\begin{array}{l}\text { Ocarina } 2 \text { Version } \\
1.0 .8 \text { by Smule }\end{array}$ & $\begin{array}{l}\text { Piano DX Version } \\
1.1 \text { by Daniel Perez }\end{array}$ & $\begin{array}{l}\text { iWriteMusic-Free } \\
\text { Version 2.3.4 by } \\
\text { iWriteMusic } \\
\text { Project }\end{array}$ & $\begin{array}{l}\text { Music Studio Lite } \\
\text { Version 2.4.1 by } \\
\text { Alexander Gross }\end{array}$ & $\begin{array}{l}\text { Maestro - the } \\
\text { Music } \\
\text { Composition App } \\
\text { Version } 2.6 \text { by } \\
\text { Darren Gates }\end{array}$ \\
\hline $\begin{array}{l}\text { Save composition to server or device or in other suitable and } \\
\text { usable format (MIDI, etc.) }\end{array}$ & $\begin{array}{l}\text { Yes. Save in } \\
\text { application. }\end{array}$ & No & $\begin{array}{l}\text { Yes. Save and delete } \\
\text { in application. Save as } \\
\text { iWriteMusic file (can } \\
\text { send but not import). }\end{array}$ & No (not free version). & $\begin{array}{l}\text { Yes. Save in } \\
\text { MusicXML format in } \\
\text { application. }\end{array}$ \\
\hline $\begin{array}{l}\text { Sharing capabilities by generating a link or uploading } \\
\text { composition to a social networking website (YouTube, } \\
\text { Facebook, Twitter, mySpace, etc.) }\end{array}$ & $\begin{array}{l}\text { Yes, only when } \\
\text { finished playing, not } \\
\text { at a later stage. Share } \\
\text { via Facebook, Twitter, } \\
\text { link for email and } \\
\text { SMS. Connect to } \\
\text { other users. Access } \\
\text { Facebook from } \\
\text { application. }\end{array}$ & No & $\begin{array}{l}\text { Yes. Email and } \\
\text { Printout. Can choose } \\
\text { pdf or jpg format for } \\
\text { email. }\end{array}$ & No (not free version). & $\begin{array}{l}\text { Yes. Export via email } \\
\text { in MusicXML format } \\
\text { (not import). }\end{array}$ \\
\hline Context-aware and self-adaptive: Online / Offline & $\begin{array}{l}\text { Can play offline but } \\
\text { not share. }\end{array}$ & Can play offline. & $\begin{array}{l}\text { Can play and save } \\
\text { offline. }\end{array}$ & Can play offline. & Can play offline. \\
\hline Track live performance & No & No & No & No & No \\
\hline Evaluation of performance (acts like a music tutor) & $\begin{array}{l}\text { Yes. Shows \% } \\
\text { progress to mastery. }\end{array}$ & No & $\begin{array}{l}\text { No, but shows how } \\
\text { you've played during } \\
\text { playback. }\end{array}$ & $\begin{array}{l}\text { No, but shows how } \\
\text { you've played during } \\
\text { playback. }\end{array}$ & $\begin{array}{l}\text { No, but shows how } \\
\text { you've played during } \\
\text { playback. }\end{array}$ \\
\hline Other comments & $\begin{array}{l}\text { Create profile (register } \\
\text { and login). Profile } \\
\text { statistics shown. } \\
\text { Connect to other } \\
\text { users. Change key } \\
\text { signature choice, } \\
\text { colour and whistle } \\
\text { mode, reverb, } \\
\text { microphone } \\
\text { sensitivity, } \\
\text { accompaniment } \\
\text { volume. }\end{array}$ & $\begin{array}{l}\text { Change interface } \\
\text { colour. Adjust key } \\
\text { width and sharp width } \\
\text { and height of piano } \\
\text { keys. Adjust volume. }\end{array}$ & $\begin{array}{l}\text { Download samples } \\
\text { and add lyrics. }\end{array}$ & $\begin{array}{l}\text { Music Studio Version } \\
\text { 2.1: Users can save } \\
\text { and export, it has a } \\
\text { wider range of } \\
\text { instruments, has MIDI } \\
\text { import and export } \\
\text { capabilities and more } \\
\text { beats to import. } \\
\text { Connect to Bluetooth } \\
\text { speakers or } \\
\text { headphones. }\end{array}$ & $\begin{array}{l}\text { Sharing function not } \\
\text { linked to email. }\end{array}$ \\
\hline
\end{tabular}




\begin{tabular}{|c|c|c|c|c|c|}
\hline FUNCTIONALITY EVALUATION CRITERIA & $\begin{array}{l}\text { Ocarina } 2 \text { Version } \\
1.0 .8 \text { by Smule }\end{array}$ & $\begin{array}{l}\text { Piano DX Version } \\
1.1 \text { by Daniel Perez }\end{array}$ & $\begin{array}{l}\text { iWriteMusic-Free } \\
\text { Version } 2.3 .4 \text { by } \\
\text { iWriteMusic Project }\end{array}$ & $\begin{array}{l}\text { Music Studio Lite } \\
\text { Version 2.4.1 by } \\
\text { Alexander Gross }\end{array}$ & $\begin{array}{l}\text { Maestro - the } \\
\text { Music } \\
\text { Composition App } \\
\text { Version 2.6 by } \\
\text { Darren Gates }\end{array}$ \\
\hline \multicolumn{6}{|l|}{ NOVICE } \\
\hline $\begin{array}{l}\text { Clef choice (the symbol at the start of the staff that defines the } \\
\text { pitch of the notes - Treble; Bass; Alto / Tenor) }\end{array}$ & No & $\begin{array}{l}\text { No. Can choose when } \\
\text { learning (observing or } \\
\text { playing). }\end{array}$ & Yes & No & Yes. Treble and Bass. \\
\hline $\begin{array}{l}\text { Key signature choice (flat or sharp: shown at the start of the staff } \\
\text { that indicates the music key) }\end{array}$ & $\begin{array}{l}\text { Yes. Choose from drop- } \\
\text { down list. }\end{array}$ & No & $\begin{array}{l}\text { Yes. Choose from drop- } \\
\text { down list. }\end{array}$ & Yes & Yes \\
\hline $\begin{array}{l}\text { Time signature choice (the tempo at the start of the staff, after the } \\
\text { key signature, that indicates the tempo of the music) }\end{array}$ & No & No & $\begin{array}{l}\text { Yes. Choose from drop- } \\
\text { down list. }\end{array}$ & $\begin{array}{l}\text { Yes, by holding in the } \\
\text { metronome button. }\end{array}$ & Yes \\
\hline Metronome indicator $(\mathrm{d}=120)$ & No & $\begin{array}{l}\text { No. Can play with } \\
\text { metronome and adjust } \\
\text { metronome tempo and } \\
\text { volume. }\end{array}$ & $\begin{array}{l}\text { Yes. Can adjust } \\
\text { metronome tempo. }\end{array}$ & $\begin{array}{l}\text { No. Can play with } \\
\text { metronome and adjust } \\
\text { metronome tempo and } \\
\text { volume. }\end{array}$ & Yes, in top menu. \\
\hline $\begin{array}{l}\text { Note and rest input on music sheet or from playing a mobile } \\
\text { instrument }\end{array}$ & $\begin{array}{l}\text { Yes. By playing: } \\
\text { blowing into the } \\
\text { microphone. }\end{array}$ & $\begin{array}{l}\text { Yes. By playing on } \\
\text { piano (can set dual } \\
\text { keyboard). Note labels } \\
\text { exist to view notes. }\end{array}$ & $\begin{array}{l}\text { Yes. Tap music sheet } \\
\text { and choose note and/or } \\
\text { rest type. }\end{array}$ & $\begin{array}{l}\text { Yes. By playing on } \\
\text { piano (can set dual } \\
\text { keyboard). Note labels } \\
\text { exist to view notes. Can } \\
\text { import beats or other } \\
\text { effects. }\end{array}$ & $\begin{array}{l}\text { Yes. Tap music sheet } \\
\text { and drag note and/or } \\
\text { rest type. }\end{array}$ \\
\hline $\begin{array}{l}\text { Chord input (e.g. three or four notes played simultaneously in } \\
\text { harmony) }\end{array}$ & No & $\begin{array}{l}\text { Yes. Can play more } \\
\text { than one note } \\
\text { simultaneously. }\end{array}$ & $\begin{array}{l}\text { Yes. Can play more } \\
\text { than one note } \\
\text { simultaneously. }\end{array}$ & $\begin{array}{l}\text { Yes. Can play more } \\
\text { than one note } \\
\text { simultaneously. }\end{array}$ & No \\
\hline Accidentals (flat, sharp, natural, etc.) & No & No & Yes & No & Yes \\
\hline Dynamics (e.g. ff, f, mf, pp, p, mp, etc.) & $\begin{array}{l}\text { No. One volume } \\
\text { adjustment. }\end{array}$ & No & Yes & No & No \\
\hline Octave signs $(8$, etc.) & $\begin{array}{l}\text { No. Can choose with } \\
\text { key signature. }\end{array}$ & $\begin{array}{l}\text { No, but can move } \\
\text { octaves with piano } \\
\text { sliders. }\end{array}$ & Yes & $\begin{array}{l}\text { No, but can move } \\
\text { octaves with piano } \\
\text { sliders. }\end{array}$ & No \\
\hline
\end{tabular}




\begin{tabular}{|c|c|c|c|c|c|}
\hline FUNCTIONALITY EVALUATION CRITERIA & $\begin{array}{l}\text { Ocarina } 2 \text { Version } \\
1.0 .8 \text { by Smule }\end{array}$ & $\begin{array}{l}\text { Piano DX Version } \\
1.1 \text { by Daniel Perez }\end{array}$ & $\begin{array}{l}\text { iWriteMusic-Free } \\
\text { Version 2.3.4 by } \\
\text { iWriteMusic Project }\end{array}$ & $\begin{array}{l}\text { Music Studio Lite } \\
\text { Version 2.4.1 by } \\
\text { Alexander Gross }\end{array}$ & $\begin{array}{l}\text { Maestro - } \\
\text { the Music } \\
\text { Composition } \\
\text { App Version } \\
2.6 \text { by } \\
\text { Darren } \\
\text { Gates }\end{array}$ \\
\hline \multicolumn{6}{|l|}{ EXPERT } \\
\hline Note relationships (tie, slur, etc.) & No & No & Yes & No & No \\
\hline $\begin{array}{l}\text { Articulation marks (staccato, accent, fermata, strings: up and down } \\
\text { bow) }\end{array}$ & No & No & Yes & No & No \\
\hline $\begin{array}{l}\text { Ornaments (modifies pitch pattern: trill, mordent, appoggiatura, } \\
\text { etc.) }\end{array}$ & No & $\begin{array}{l}\text { No. Has a pedal to } \\
\text { extend note sound. }\end{array}$ & Yes & No & No \\
\hline Break input ('or //) & No & No & Yes & No & No \\
\hline Repetition and coda signs (repeat signs, etc.) & No & No & Yes & No & No \\
\hline Modulation (shift to another key at any stage) & No & No & Yes & No & No \\
\hline $\begin{array}{l}\text { Transposition (move notes up or down in pitch by a constant } \\
\text { interval) }\end{array}$ & No & No & $\begin{array}{l}\text { Yes. Can transpose at } \\
\text { any time. }\end{array}$ & No & Yes \\
\hline
\end{tabular}

Table 5.1: A framework to evaluate mobile application functionality for music composition (applications 1-5) 
Table 5.2: A framework to evaluate mobile application functionality for music composition (applications 6-10)

\begin{tabular}{|c|c|c|c|c|c|}
\hline FUNCTIONALITY EVALUATION CRITERIA & $\begin{array}{l}\text { Pianist Version } 1.9 \\
\text { by MooCowMusic } \\
\text { Ltd. }\end{array}$ & $\begin{array}{l}\text { Music Composer } \\
\text { Version } 2.4 \text { by } \\
\text { Kejian Jin }\end{array}$ & $\begin{array}{l}\text { Symphony Version } \\
\text { 2.6.4 by Xenon } \\
\text { Labs, LLC }\end{array}$ & $\begin{array}{l}\text { iComposer Version } \\
2.0 .3 \text { by } \mathrm{JL}\end{array}$ & $\begin{array}{l}\text { iWriteMusic } \\
\text { Version } 2.3 .4 \text { by } \\
\text { iWriteMusicProject }\end{array}$ \\
\hline \multicolumn{6}{|l|}{ GENERIC } \\
\hline Mobile application type: Single / collaborative users & Single & Single & Single & Single & Single \\
\hline Music sheets (staff and bars with bar numbers) & No & $\begin{array}{l}\text { Yes. Staff and bars. No } \\
\text { bar numbers. }\end{array}$ & $\begin{array}{l}\text { Yes. Staff and bars. No } \\
\text { bar numbers. }\end{array}$ & $\begin{array}{l}\text { Yes. Staff (more than } \\
\text { one) with bars. No bar } \\
\text { numbers. }\end{array}$ & $\begin{array}{l}\text { Yes. Staff, bars and bar } \\
\text { numbers. }\end{array}$ \\
\hline Turn music sheet pages & No & No & Yes & Yes & $\begin{array}{l}\text { Yes. Swipe or tap next } \\
\text { and previous buttons to } \\
\text { scroll sheet pages. }\end{array}$ \\
\hline Instrument choice (range of instruments) & No. Only piano. & No. Only piano. & Yes. There is a range. & $\begin{array}{l}\text { Yes. Can choose from a } \\
\text { range in setup step } 2 \\
\text { (linked to clef choice). }\end{array}$ & Yes. There is a range. \\
\hline Real-time audio feedback & Yes, as a user plays. & Yes, as a user plays. & $\begin{array}{l}\text { Yes, as a user taps to } \\
\text { insert notes. }\end{array}$ & No & $\begin{array}{l}\text { Yes, as a user taps to } \\
\text { insert notes. }\end{array}$ \\
\hline Music score playback at any stage & $\begin{array}{l}\text { Yes. Has a record and } \\
\text { playback function. }\end{array}$ & Yes & $\begin{array}{l}\text { Yes. Can adjust tempo. } \\
\text { Can play back note for } \\
\text { note by using arrow } \\
\text { keys on bottom menu. } \\
\text { Can edit playback } \\
\text { settings: Page } \\
\text { automatically (on/off) } \\
\text { and Notes light up } \\
\text { (on/off). }\end{array}$ & Yes & Yes - requires iOS 5. \\
\hline $\begin{array}{l}\text { Multiple melodic lines captured and simultaneous } \\
\text { playback: Counterpoint (e.g. two or three melodic lines } \\
\text { played at the same time) }\end{array}$ & $\begin{array}{l}\text { Yes, on dual keyboard, } \\
\text { and record and } \\
\text { playback. }\end{array}$ & No & Yes & $\begin{array}{l}\text { Yes. Can add, edit and } \\
\text { delete lines. }\end{array}$ & Yes \\
\hline
\end{tabular}




\begin{tabular}{|c|c|c|c|c|c|}
\hline FUNCTIONALITY EVALUATION CRITERIA & $\begin{array}{l}\text { Pianist Version } 1.9 \\
\text { by MooCowMusic } \\
\text { Ltd. }\end{array}$ & $\begin{array}{l}\text { Music Composer } \\
\text { Version } 2.4 \text { by } \\
\text { Kejian Jin }\end{array}$ & $\begin{array}{l}\text { Symphony Version } \\
\text { 2.6.4 by Xenon Labs, } \\
\text { LLC }\end{array}$ & $\begin{array}{l}\text { iComposer Version } \\
2.0 .3 \text { by JL }\end{array}$ & $\begin{array}{l}\text { iWriteMusic } \\
\text { Version } 2.3 .4 \text { by } \\
\text { iWriteMusicProje } \\
\text { ct }\end{array}$ \\
\hline $\begin{array}{l}\text { Composition editing (clef, key signature, time signature, } \\
\text { notes and rests, instrument, etc.) }\end{array}$ & $\begin{array}{l}\text { Yes. Delete note, last } \\
\text { track or entire song. } \\
\text { Can adjust volume. }\end{array}$ & $\begin{array}{l}\text { Yes. Change note } \\
\text { lengths from drop- } \\
\text { down list or menu. } \\
\text { Delete and add notes. } \\
\text { Key and time signature } \\
\text { change. }\end{array}$ & $\begin{array}{l}\text { Yes. All functions. Has } \\
\text { buttons to copy, paste } \\
\text { and delete notes and } \\
\text { rests. }\end{array}$ & $\begin{array}{l}\text { Yes. All functions. Has } \\
\text { undo and redo buttons } \\
\text { on menu. }\end{array}$ & Yes. All functions. \\
\hline $\begin{array}{l}\text { Save composition to server or device or in other suitable and } \\
\text { usable format (MIDI, etc.) }\end{array}$ & $\begin{array}{l}\text { Yes. Save and delete in } \\
\text { application. }\end{array}$ & $\begin{array}{l}\text { Yes, by email as a .wav } \\
\text { file. }\end{array}$ & $\begin{array}{l}\text { Yes. Save and delete in } \\
\text { application. }\end{array}$ & $\begin{array}{l}\text { Yes. Save in application } \\
\text { or upload to Music Box } \\
\text { on website if a user } \\
\text { account exists. Can edit } \\
\text { 'automatically save' } \\
\text { settings: Every } 2,5,10, \\
30 \text { minutes. }\end{array}$ & $\begin{array}{l}\text { Yes. Save and delete } \\
\text { in application. Save / } \\
\text { export as } \\
\text { iWriteMusic file } \\
\text { (can import and } \\
\text { export via email), or } \\
\text { as pdf (also send pdf } \\
\text { to other apps), jpg or } \\
\text { standard MIDI file. } \\
\text { Can save much } \\
\text { detail, e.g. change } \\
\text { sheet layout, amount } \\
\text { of bars shown, etc., } \\
\text { before emailing or } \\
\text { printing. AutoSave } \\
\text { on/off. }\end{array}$ \\
\hline $\begin{array}{l}\text { Sharing capabilities by generating a link or uploading } \\
\text { composition to a social networking website (YouTube, } \\
\text { Facebook, Twitter, mySpace, etc.) }\end{array}$ & No & $\begin{array}{l}\text { Yes. Email as a .wav } \\
\text { file. }\end{array}$ & $\begin{array}{l}\text { Yes. Email within } \\
\text { application - type in } \\
\text { email address. }\end{array}$ & $\begin{array}{l}\text { Yes. Email: Export file } \\
\text { in MusicXML or } \\
\text { MIDI format. Upload } \\
\text { to Music Box on } \\
\text { website if a user account } \\
\text { exists. }\end{array}$ & $\begin{array}{l}\text { Yes. Email and } \\
\text { Printout. Export pdf, } \\
\text { jpg or standard } \\
\text { MIDI file format via } \\
\text { email. Can } \\
\text { export/import } \\
\text { iWriteMusic file via } \\
\text { email. Printouts via } \\
\text { AirPrint - requires } \\
\text { iOS } 4.2 \text { or higher. }\end{array}$ \\
\hline
\end{tabular}




\begin{tabular}{|c|c|c|c|c|c|}
\hline FUNCTIONALITY EVALUATION CRITERIA & $\begin{array}{l}\text { Pianist Version } 1.9 \\
\text { by MooCowMusic } \\
\text { Ltd. }\end{array}$ & $\begin{array}{l}\text { Music Composer } \\
\text { Version } 2.4 \text { by } \\
\text { Kejian Jin }\end{array}$ & $\begin{array}{l}\text { Symphony Version } \\
\text { 2.6.4 by Xenon } \\
\text { Labs, LLC }\end{array}$ & $\begin{array}{l}\text { iComposer Version } \\
2.0 .3 \text { by } \mathrm{JL}\end{array}$ & $\begin{array}{l}\text { iWriteMusic } \\
\text { Version } 2.3 .4 \text { by } \\
\text { iWriteMusicProject }\end{array}$ \\
\hline Context-aware and self-adaptive: Online / Offline & $\begin{array}{l}\text { Can play and save } \\
\text { offline. }\end{array}$ & $\begin{array}{l}\text { Can play offline and } \\
\text { create email draft } \\
\text { message. }\end{array}$ & $\begin{array}{l}\text { Can play and save } \\
\text { offline. Cannot email. }\end{array}$ & $\begin{array}{l}\text { Can play and save } \\
\text { offline and create email } \\
\text { draft message. }\end{array}$ & $\begin{array}{l}\text { Can play and save } \\
\text { offline and create email } \\
\text { draft message. }\end{array}$ \\
\hline Track live performance & No & No & No & No & No \\
\hline Evaluation of performance (acts like a music tutor) & $\begin{array}{l}\text { No, but shows how } \\
\text { you've played during } \\
\text { playback. }\end{array}$ & No & $\begin{array}{l}\text { No, but shows how } \\
\text { you've played during } \\
\text { playback. }\end{array}$ & $\begin{array}{l}\text { No, but shows how } \\
\text { you've played during } \\
\text { playback. }\end{array}$ & $\begin{array}{l}\text { No, but shows how } \\
\text { you've played during } \\
\text { playback. }\end{array}$ \\
\hline Other comments & $\begin{array}{l}\text { Change number of } \\
\text { piano keys shown. } \\
\text { Adjust volume. }\end{array}$ & $\mathrm{N} / \mathrm{A}$ & $\begin{array}{l}\text { Can load existing } \\
\text { compositions, from a } \\
\text { URL or sample songs. } \\
\text { Can change colour of } \\
\text { interface (staff, etc.). }\end{array}$ & $\begin{array}{l}\text { Create an account on } \\
\text { website and log in in } \\
\text { application. Setup has } 5 \\
\text { steps to create a new } \\
\text { composition (cover page } \\
\text { with details, etc.). Can } \\
\text { open compositions in } \\
\text { application from email } \\
\text { in MusicXML format. } \\
\text { Can open a plain XML } \\
\text { file from email or } \\
\text { website. }\end{array}$ & $\begin{array}{l}\text { Download samples and } \\
\text { add lyrics. Edit font } \\
\text { size of lyrics and chord } \\
\text { symbols. }\end{array}$ \\
\hline
\end{tabular}




\begin{tabular}{|c|c|c|c|c|c|}
\hline $\begin{array}{l}\text { FUNCTIONALITY EVALUATION } \\
\text { CRITERIA }\end{array}$ & $\begin{array}{l}\text { Pianist Version } 1.9 \text { by } \\
\text { MooCowMusic Ltd. }\end{array}$ & $\begin{array}{l}\text { Music Composer } \\
\text { Version } 2.4 \text { by Kejian } \\
\text { Jin }\end{array}$ & $\begin{array}{l}\text { Symphony } \\
\text { Version 2.6.4 by } \\
\text { Xenon Labs, LLC }\end{array}$ & $\begin{array}{l}\text { iComposer Version } \\
2.0 .3 \text { by } \mathrm{JL}\end{array}$ & $\begin{array}{l}\text { iWriteMusic } \\
\text { Version 2.3.4 by } \\
\text { iWriteMusicProje } \\
\text { ct }\end{array}$ \\
\hline \multicolumn{6}{|l|}{ NOVICE } \\
\hline $\begin{array}{l}\text { Clef choice (the symbol at the start of the staff that } \\
\text { defines the pitch of the notes - Treble; Bass; Alto / } \\
\text { Tenor) }\end{array}$ & No & No & Yes. Treble and bass. & $\begin{array}{l}\text { Yes. Choose } \\
\text { instrument and clef } \\
\text { automatically selected } \\
\text { (setup step 2). }\end{array}$ & Yes \\
\hline $\begin{array}{l}\text { Key signature choice (flat or sharp: shown at the start of } \\
\text { the staff that indicates the music key) }\end{array}$ & No & $\begin{array}{l}\text { Yes. Choose from drop- } \\
\text { down list. Not shown on } \\
\text { staff. }\end{array}$ & Yes & Yes (setup step 3). & $\begin{array}{l}\text { Yes. Choose from } \\
\text { drop-down list. }\end{array}$ \\
\hline $\begin{array}{l}\text { Time signature choice (the tempo at the start of the } \\
\text { staff, after the key signature, that indicates the tempo } \\
\text { of the music) }\end{array}$ & No & $\begin{array}{l}\text { Yes. Choose from drop- } \\
\text { down list. Not shown on } \\
\text { staff. }\end{array}$ & Yes & Yes (setup step 4). & $\begin{array}{l}\text { Yes. Choose from } \\
\text { drop-down list. }\end{array}$ \\
\hline Metronome indicator $(\mathrm{d}=120)$ & $\begin{array}{l}\text { No. Can play with } \\
\text { metronome and adjust } \\
\text { metronome tempo and } \\
\text { volume. }\end{array}$ & No & $\begin{array}{l}\text { Yes, but shown in } \\
\text { bottom menu; not on } \\
\text { sheet. Can edit bpm. }\end{array}$ & Yes, but not on sheet. & $\begin{array}{l}\text { Yes. Can adjust } \\
\text { metronome tempo. }\end{array}$ \\
\hline $\begin{array}{l}\text { Note and rest input on music sheet or from playing a } \\
\text { mobile instrument }\end{array}$ & $\begin{array}{l}\text { Yes. By playing on piano } \\
\text { (can set dual keyboard). } \\
\text { Note labels exist to view } \\
\text { notes. }\end{array}$ & $\begin{array}{l}\text { Yes. By playing on piano. } \\
\text { Choose note length from } \\
\text { drop-down list. Choose rests } \\
\text { from menu. Note labels exist } \\
\text { to view notes. }\end{array}$ & $\begin{array}{l}\text { Yes. Tap music sheet } \\
\text { and choose note } \\
\text { and/or rest type. }\end{array}$ & $\begin{array}{l}\text { Yes. Tap music sheet } \\
\text { and choose note } \\
\text { and/or rest type. Extra } \\
\text { function: Can record } \\
\text { voice and transcribe it } \\
\text { onto sheet (hemming). }\end{array}$ & $\begin{array}{l}\text { Yes. Tap music sheet } \\
\text { and choose note } \\
\text { and/or rest type. }\end{array}$ \\
\hline $\begin{array}{l}\text { Chord input (e.g. three or four notes played } \\
\text { simultaneously in harmony) }\end{array}$ & $\begin{array}{l}\text { Yes. Can play more than } \\
\text { one note simultaneously. }\end{array}$ & $\begin{array}{l}\text { Yes. Can play more than one } \\
\text { note simultaneously, but } \\
\text { listed separately on staff. }\end{array}$ & Yes & Yes & $\begin{array}{l}\text { Yes. Can play more } \\
\text { than one note } \\
\text { simultaneously. }\end{array}$ \\
\hline Accidentals (flat, sharp, natural, etc.) & No & Yes & Yes & Yes & Yes (more added). \\
\hline Dynamics (e.g. ff, f, mf, pp, p, mp, etc.) & $\begin{array}{l}\text { No. One volume } \\
\text { adjustment. }\end{array}$ & No & No & Yes & Yes \\
\hline Octave signs $(8$, etc. $)$ & $\begin{array}{l}\text { No, but can move octaves } \\
\text { with piano sliders. }\end{array}$ & $\begin{array}{l}\text { No, but can move octaves } \\
\text { with piano sliders. }\end{array}$ & No & Yes & Yes \\
\hline & & & & & \\
\hline
\end{tabular}




\begin{tabular}{|c|c|c|c|c|c|}
\hline $\begin{array}{c}\text { FUNCTIONALITY EVALUATION } \\
\text { CRITERIA }\end{array}$ & $\begin{array}{l}\text { Pianist Version } 1.9 \text { by } \\
\text { MooCowMusic Ltd. }\end{array}$ & $\begin{array}{l}\text { Music Composer } \\
\text { Version } 2.4 \text { by Kejian } \\
\text { Jin }\end{array}$ & $\begin{array}{l}\text { Symphony } \\
\text { Version } 2.6 .4 \text { by } \\
\text { Xenon Labs, LLC }\end{array}$ & $\begin{array}{l}\text { iComposer Version } \\
2.0 .3 \text { by } \mathrm{JL}\end{array}$ & $\begin{array}{l}\text { iWriteMusic } \\
\text { Version } 2.3 .4 \text { by } \\
\text { iWriteMusicProje } \\
\text { ct }\end{array}$ \\
\hline \multicolumn{6}{|l|}{ EXPERT } \\
\hline Note relationships (tie, slur, etc.) & No & No & Yes & Yes & Yes \\
\hline $\begin{array}{l}\text { Articulation marks (staccato, accent, fermata, strings: } \\
\text { up and down bow) }\end{array}$ & No & No & No & Yes & Yes \\
\hline $\begin{array}{l}\text { Ornaments (modifies pitch pattern: trill, mordent, } \\
\text { appoggiatura, etc.) }\end{array}$ & $\begin{array}{l}\text { No. Has sustain pedal to } \\
\text { extend note sound and } \\
\text { expression pedal to control } \\
\text { volume. }\end{array}$ & No & No & Yes & Yes \\
\hline Break input ('or //) & No & No & No & No & Yes \\
\hline Repetition and coda signs (repeat signs, etc.) & No & Yes & No & Yes & Yes \\
\hline Modulation (shift to another key at any stage) & No & No & No & Yes & Yes \\
\hline $\begin{array}{l}\text { Transposition (move notes up or down in pitch by a } \\
\text { constant interval) }\end{array}$ & No & Yes & Yes & Yes & Yes \\
\hline
\end{tabular}


The evaluation framework proposed in section 4 is applied to ten diverse mobile applications for music composition in tables 5.1 and 5.2. In the final section of the paper the research questions will be answered and the findings of the application of the framework will be summarised.

\section{Conclusion}

In conclusion, the research questions are revisited.

\section{How can the functionality of mobile applications for music composition be evaluated?}

It was important to find evidence of functionality requirements from the literature, from one of the authors' knowledge of music and especially the questionnaire that was completed by students and lecturers of music at tertiary level. The questionnaire results confirmed the validity and importance of the functionality criteria. A proper functionality list, grouped into three sub-categories related to user requirements, was needed to conduct the evaluation process. Before a user can start composing music, certain prerequisites need to be met, for example, working on a blank music sheet, choosing the clef, key and time signatures, etc. The list created by the authors supported the process of evaluating the mobile applications against the functionality criteria.

\section{What is needed when composing music?}

It was evident from the literature review, questionnaire and the research results that an extensive list of functionalities needs to be supported by a mobile application in order for it to be used to compose music in great detail. The ten mobile applications evaluated are all intended for single users. Note and rest inputs are possible by playing an instrument (mostly a piano) or by adding notes or rests on a music sheet by tapping or dragging from the menu. Some of the applications (Ocarina 2, Piano DX, Music Studio Lite, Pianist and Music Composer) that use an instrument for note and rest inputs have other functionality limitations - no music sheet with staff and bars, no clef, key signature, time signature or metronome indicator. This also limits the functionality of saving sheet music and limits overall composition editing capabilities, for example, a mobile application that does not offer dynamic or articulation input, limits composition editing. Composition editing is very important as composers edit their music constantly throughout the composition process. Four applications (iWriteMusic-Free, Symphony, iComposer and iWriteMusic) support extensive editing for all functions.

The more expensive applications presented more functionality. For example, one free application (iWriteMusic-Free) and two more expensive applications (iComposer and iWriteMusic) have both modulation and transposition capabilities whereas some of the free and less expensive applications (Ocarina 2, Piano DX, Music Studio Lite and Pianist) do not have modulation and transposition capabilities. These capabilities are important for expert users who are familiar with the usefulness of these functionalities in composing music. A clear correlation between the cost of an application and the range of instruments available was also noted.

Real-time audio feedback and playback functionalities are very important as a user should be able to listen to the music as it is being created or at any stage during composition. Most of the applications (Ocarina 2, iWriteMusic-Free, Music Studio Lite, Pianist, Music Composer, Symphony and iWriteMusic) provide real-time audio feedback and playback functionalities. It was noted that multiple melodic lines (counterpoint) are better supported 
by the more expensive applications (Symphony, iComposer and iWriteMusic) which use music sheets for note and rest inputs. One of the free applications (iWriteMusic-Free) also supports this function. This is very useful for composers who compose music for more than one instrument, like orchestral music.

None of the applications support live performance tracking, which is very complex to develop. The majority of applications (iWriteMusic-Free, Music Studio Lite, Maestro - the Music Composition App, Pianist, Symphony, iComposer and iWriteMusic) do not evaluate a user's performance but during playback show a user which notes were used as input or how the music was played. All the applications evaluated can be used offline. Limitations in saving and sharing (via email and social networking websites) were apparent in offline mode.

\section{How can music composers collaborate?}

Saving and sharing capabilities is an important part of the functionality requirements. This is necessary for a user to not lose the composition and to be able to return to working on it at a later stage. It is also useful to share the composition with oneself or with other people. It was emphasised in the literature that sharing capabilities are important as users enjoy connecting with other users with the same interests.

Most applications (Ocarina 2, iWriteMusic-Free, Maestro - the Music Composition App, Pianist, Symphony, iComposer and iWriteMusic) have the functionality to save a composition in the application. Some mobile applications (Ocarina 2, iWriteMusic-Free, Maestro - the Music Composition App, Music Composer, Symphony, iComposer and iWriteMusic) offer sharing via email by exporting the file in a suitable format (e.g. MIDI, MusicXML, WAV) for use with other music composition and editing software. Some applications offer a more advanced level of sharing, like uploading the composition to the company website (iComposer) or to a social networking website like Facebook or Twitter (Ocarina 2). Two applications (iWriteMusic-Free and iWriteMusic) have the functionality to print the composition sheet music, which is an important requirement and a very useful function in music composition.

\section{What mobile applications are available for music composition?}

A wide range of mobile applications is available from the iTunes App Store under the music category, of which only a few mobile applications are specifically aimed at music composition. Although free applications are available, some have limited functionality. It is clear from the literature review and research results that the more expensive applications offer users more functionality. Whereas free applications (Ocarina 2, Piano DX, iWriteMusic-Free and Music Studio Lite) did not meet all functionality requirements, the more expensive applications (Symphony, iComposer and iWriteMusic) met most functionality requirements. The type of application is also related to the type of user. Novices might find the basic, free applications usable, whereas expert users might require more functionality in a mobile application for composing music.

Developers should take the type of users into account when developing such applications. For example, novice users would require basic functionality and expert users would require shortcuts and added functionality. When an application is intended for novice users, it should be taken into account that these users' knowledge of music theory might be limited and that the application should offer the necessary support for users to carry out music composition tasks with ease. When an application is intended for expert users, developers should be aware of these users' demands for increased functionality and should aim to meet the users' 
requirements that match their knowledge and skill levels. The development of generic applications intended for all types of users will be even more complex as the applications should cater for the needs of both novices and experts.

In the future we will probably see an increase in the functionality and use of mobile applications for music composition by all types of mobile users. The development of contextaware and self-adaptive mobile applications is a complex task and developers should aim to meet most functionality requirements when developing mobile applications for music composition.

Further research should explore human computer interaction as an evaluation criterion of mobile applications for music composition.

\section{References}

Arrasvuori, J. \& Holm, J. 2007. Designing Interactive Music Mixing Applications for Mobile Devices. DIMEA. Proceedings of the 2nd International Conference on Digital Interactive Media in Entertainment and Arts, p. 20-27. [Online] Available: http://dl.acm.org/citation.cfm?id=1306827 [Cited: 12 October 2012].

Bernardini, N. \& De Poli, G. 2007. The Sound and Music Computing Field: Present and Future. Journal of New Music Research, vol. 36, no. 3, p. 143-148.

Behrendt, F. n.d. From Calling a Cloud to Finding the Missing Track: Artistic Approaches to Mobile Music. [Online] Available: http://www.pdfport.com/view/567035-fromcalling-a-cloud-to-finding-the-missing-track-artistic.html [Cited: 20 October 2012].

Bryan-Kinns, N. 2004. Mobile Group Music Improvisation. 1st International Conference on Engagability $\sigma \quad$ Design. [Online] Available: http://www.eecs.qmul.ac.uk/ nickbk/papers/nickbk eandd full.pdf [Cited: 15 October 2012]

Chen, W. \& Hirschheim, R. 2004. A Paradigmatic and Methodological Examination of Information Systems Research from 1991 to 2001. Information Systems Journal, vol. 14, p. 197-235.

Chiang, C., Chiu, S., Dharma, A.A.G. \& Tomimatsu, K. 2012. Birds on Paper: An Alternative Interface to Compose Music by Utilizing Sketch Drawing and Mobile Device. TEI. Proceedings of the Sixth International Conference on Tangible, Embedded and Embodied Interaction, p. 201-204. [Online] Available: http://dl.acm.org/citation.cfm?doid=2148131.2148175 [Cited: 14 October 2012]

Elliot, S. 2011. Transdisciplinary Perspectives on Environmental Sustainability: A Resource Base and Framework for IT-Enabled Business Transformation. MIS Quarterly, vol. 35 , no. 1 , p. $197-236$.

Essl, G. \& Rohs, M. 2009. Interactivity for Mobile Music-Making. Organised Sound, vol. 14, no. 2, p. 197-207. 
Floch, J., Frá, C., Fricke, R., Geihs, K., Wagner, M., Lorenzo, J., Soladana, E., Mehlhase, S., Paspallis, N., Rahnama, H., Ruiz, P.A. \& Scholz, U. 2012. Playing MUSIC Building Context-aware and Self-adaptive Mobile Applications. Software - Practice and Experience. [Online] Available: http://onlinelibrary.wiley.com/doi/10.1002/spe.2116/abstract [Cited: 15 October 2012].

Hamilton, R., Smith, J. \& Wang, G. 2011. Social Composition: Musical Data Systems for Expressive Mobile Music. Leonardo Music Journal, vol. 21, p. 57-64.

iTunes App Store, 2013. [Online] Available: https://itunes.apple.com/za/genre/iosmusic/id6011? $\mathrm{mt}=8$ [Cited: 29 October 2013].

Kroeze, J.H. 2012. Transdisciplinarity in IS: The Next Frontier in Computing Disciplines. Sprouts: Working Papers in Information Systems, vol. 14, no. 2. [Online] Available: http://sprouts.aisnet.org/12-2 [Cited: 26 February 2014].

Liu, Z., Feng, Y. \& Li, B. 2012. MusicScore: Mobile Music Composition for Practice and Fun. MM. [Online] Available: http://iqua.ece.toronto.edu/ bli/papers/zliumultimedia12.pdf [Cited: 15 October 2012].

Research Design. 2013. [Online] Available: http://www4.uwsp.edu/psych/stat/1/expdes.htm [Cited: 14 May 2013].

Savage, N.S., Ali, S.R. \& Chavez, N.E. 2010. Mmmmm: A Multi-modal Mobile Music Mixer. Proceedings of the 2010 Conference on New Interfaces for Musical Expression (NIME). [Online]

Available: http://www.nime.org/proceedings/2010/nime2010_395.pdf [Cited: 19 October 2012].

Vonk, M.E., Tripodi, T. \& Epstein, I. 2007. Research Techniques for Clinical Social Workers. 2nd ed. New York: Columbia University Press. [Online] Available: http://www.omnilogos.com/2012/03/12/systematic-observation/ [Cited: 20 November 2012]

Weber, R. 2004. Editor's Comments: The Rhetoric of Positivism versus Interpretivism: A Personal View. MIS Quarterly, vol. 28, no. 1, p. iii-xii.

Wikipedia. App Store (iOS). 2013. [Online] Available: http://en.wikipedia.org/wiki/App Store (iOS) [Cited: 14 May 2013].

Woldecke, B., Geiger, C., Reckter, H. \& Schulz, F. 2010. ANTracks 2.0 - Generative Music on Multiple Multitouch Devices. Proceedings of the 2010 Conference on New Interfaces for Musical Expression (NIME). [Online] Available: http://www.nime.org/proceedings/2010/nime2010_348.pdf [Cited: 19 October 2012].

Zhou, Y., Percival, G., Wang, X., Wang, Y. \& Zhao, S. 2010. MOGCLASS: A Collaborative System of Mobile Devices for Classroom Music Education. MM. [Online] Available: http://www.comp.nus.edu.sg/ yzhou86/mmshc05843-zhou.pdf [Cited: 17 October 2012] 